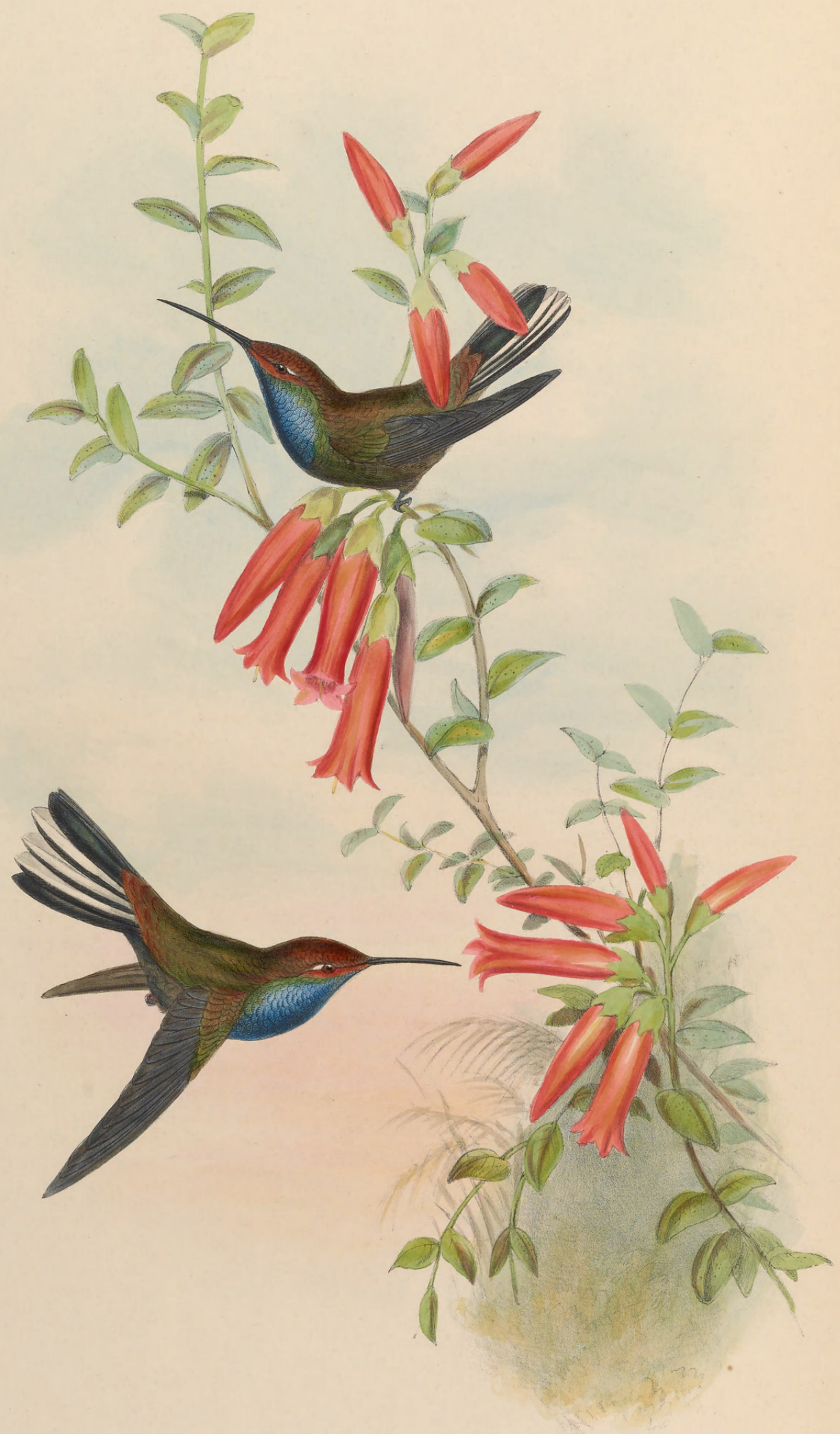

UROCHROA BOTGIERT。 


\section{UROCHROA BOUGUERI.}

\section{Pied-tail.}

Trochilus Bougueri, Bourc. Compte rend. de l'Acad. des Sci., tom. xxxii. p. 186.

Coeligena bougueri, Bonap. Rev. et Mag. de Zool. 1854, p. 252.

Coeligena Bouguieri, Reichenb. Aufz. der Colibris, p. 7.-Ib. Troch. enumer., p. 3.

THE discovery of this new and very remarkable Humming Bird is due to the researches of M. Bourcier, who, during his late visit to Ecuador, obtained many new species and much valuable information respecting the Trochilidx. The present is certainly not among the least important of these discoveries, the bird being of large size and possessing several characters peculiar to itself; at the same time, it must be admitted that its colours are not so contrasted or lustrous as those of some of its congeners. Its general contour and the form of its bill and wings rendering it impossible to associate it with the members of any previously established genus, and the colouring of its tail-black, interspersed with white-presenting a character quite unique; I have been induced to constitute it the type of a new genus, the propriety of which must be determined by time and further research, which will probably reveal to us other species of the form; for it must be recollected that our knowledge of the productions of the great primeval forests of Southern America is even yet very imperfect, although each succeeding year has for some time past made us more and more acquainted with them.

Both Sir William Jardine and myself have received specimens of this bird from Professor Jameson, whose researches in the forests round Quito have so frequently been attended with satisfactory results. M. Bourcier's specimens were obtained in the great woods of the hot regions of Nanégan.

Lores reddish brown; space under the eye, forehead, all the upper surface and upper tail-coverts dark coppery bronze, with a tinge of green on the greater wing-coverts, and becoming of a brighter or more coppery hue on the upper tail-coverts; wings dark purple; two centre and the outer tail-feather on each side purplish black; the remaining tail-feathers white, broadly margined externally, and very slightly fringed on the apical portion of their inner webs with purplish black; throat shining greenish blue, passing into grass-green on the sides of the neck; all the under surface dark olive, glossed with grass-green.

The figures are the size of life. The plant is the Ceratostema longiflorum. 


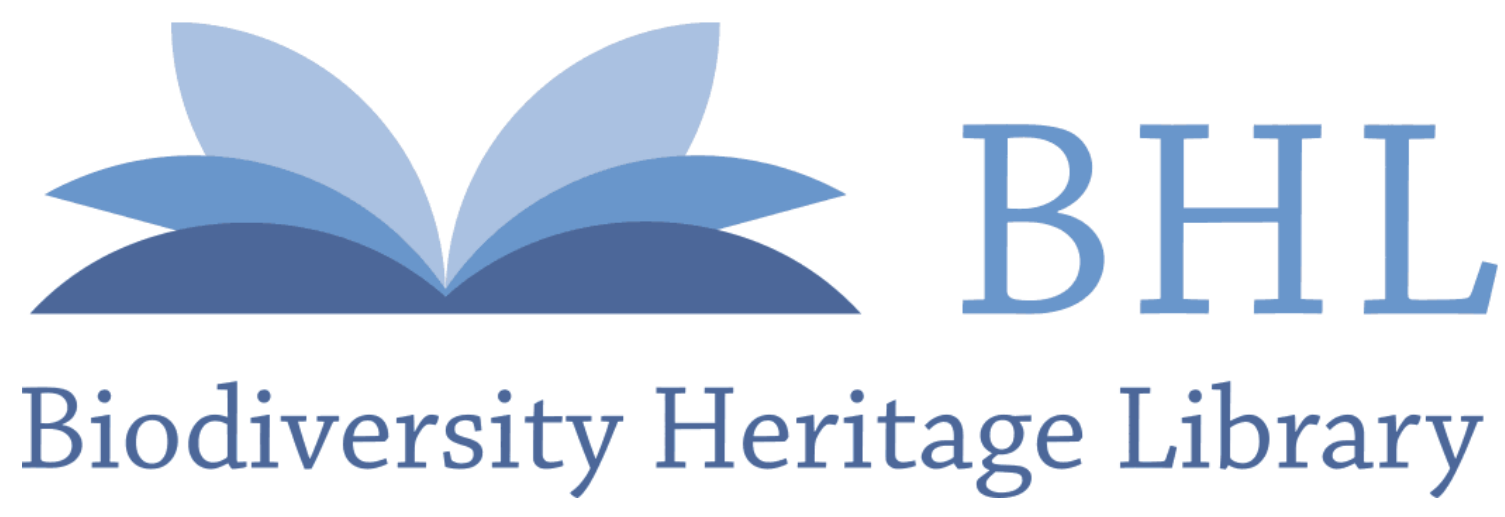

Gould, John. 1852. "Urochroa bougueri, Pied-tail. [PI. 57]." A monograph of the Trochilidae, or family of humming-birds 2, https://doi.org/10.5962/p.316866.

View This Item Online: https://www.biodiversitylibrary.org/item/108332

DOI: https://doi.org/10.5962/p.316866

Permalink: https://www.biodiversitylibrary.org/partpdf/316866

\section{Holding Institution}

Smithsonian Libraries

\section{Sponsored by}

Smithsonian Institution Libraries

\section{Copyright \& Reuse}

Copyright Status: NOT_IN_COPYRIGHT

This document was created from content at the Biodiversity Heritage Library, the world's largest open access digital library for biodiversity literature and archives. Visit BHL at https://www.biodiversitylibrary.org. 